\title{
Studies with long term storage of cut flowers of Hydrangea macrophylla
}

\author{
Estudios de almacenamiento prolongado de flores cortadas \\ de Hydrangea macrophylla
}

\author{
Flavia Schiappacasse $^{1 *}$, Claudia Moggia ${ }^{1}$, Romina Contreras ${ }^{1}$
}

\begin{abstract}
Hydrangea macrophylla subsp. macrophylla var. macrophylla has been widely cultivated as a garden and potted plant. In addition, cut flower cultivars have been developed and have been recently introduced in Chile for export to the United States. Currently, cut flowers are air-shipped in cartons with their stems placed into individual water tubes. There is little information about postharvest management. This study was conducted to explore the feasibility of exporting hydrangea cut flower stems via sea freight at the classic harvesting stage, also called antique stage. Flower stems were obtained from a commercial grower located in Central Chile. Four treatments were established: precooling (stems placed at $0.5^{\circ} \mathrm{C}$ before packing), precooling + fungicide pyrimethanil or sodium bisulphite, and a non-precooled group of flowers (immediate packing). Water tubes were placed in the stem ends. The stems were packed in cartons and placed in a $0.5^{\circ} \mathrm{C}$ cold room.

After 20 days of storage at $0.5^{\circ} \mathrm{C}$, flower vase life was 7-9 days. In contrast, an additional experiment showed that flower stems that were stored for 35 days had a vase life of only 2 days. There was no difference in vase life between precooled and non-precooled stems. The average total water uptake per stem was $43 \mathrm{ml}$. Botrytis infection was observed only in one out of two treatments without fungicide, where incidence was $12.5 \%$, therefore the effect of fungicides was not evaluated. It was concluded that sea shipping to the United States of hydrangea cut flowers harvested at the antique stage, would be technically feasible.
\end{abstract}

Key words: stem precooling, vase life, sea transport, cut flower

\section{RESUMEN}

Hydrangea macrophylla subsp. macrophylla var. macrophylla ha sido ampliamente cultivada como planta de jardín y planta en maceta. Adicionalmente, se han desarrollado e introducido recientemente en Chile cultivares de flor cortada, para su exportación a Estados Unidos. Actualmente, las flores cortadas se transportan vía aérea en cajas de cartón, con un tubo con agua puesto en la base de sus tallos. Hay poca información disponible acerca del manejo poscosecha. Este estudio fue realizado con el fin de explorar la factibilidad de exportar varas florales de hortensia vía marítima, cortadas en el estado de madurez clásico, también llamado estado antique. Se obtuvieron varas florales de un productor comercial ubicado en Chile Central. Se establecieron cuatro tratamientos: prefrío (varas puestas a $0,5{ }^{\circ} \mathrm{C}$ antes de empacar), prefrío + fungicida pyrimethanil o bisulfito de sodio y un grupo de flores sin prefrío (empaque inmediato). Se pusieron tubos con agua en la base de los tallos. Las varas fueron empacadas en cajas de cartón y puestas en cámara de frío a $0,5^{\circ} \mathrm{C}$.

Después de 20 días de almacenamiento a 0,5 ${ }^{\circ} \mathrm{C}$, la vida útil (o vida en florero) fue de 7-9 días. En contraste, un experimento adicional mostró que las varas que fueron almacenadas por 35 días tuvieron una vida útil de solo 2 días. No hubo diferencia en cuanto a vida útil entre varas con o sin prefrío. El promedio de absorción de agua por vara fue de $43 \mathrm{ml}$. Se observó ataque de Botrytis solo en uno de los dos tratamientos sin fungicida, donde la incidencia fue de 12,5\%, por lo que el efecto de los fungicidas no fue evaluado. Se concluyó que el transporte vía marítima a Estados Unidos de flores cortadas en el estado antique sería técnicamente posible.

Palabras clave: prefrío de varas, vida en florero, vase life, transporte marítimo, flor cortada

\section{Introduction}

Chile is a country that has long been known for its fruit industry. During the past 30 years, the country has developed satisfactory export logistics and a modern infrastructure that also favors the cut flower export sector. This last sector, which contributes with 2,500 to 4,500 M US\$ per year (Traub and Vicuña, 2012), faces a strong competition from neighboring countries and others countries from

\footnotetext{
$1 \quad$ Facultad de Ciencias Agrarias, Universidad de Talca, Casilla 747, Talca, Chile

* Corresponding author: fschiap@utalca.cl
}

Fecha de Recepción: 29 Julio, 2014.

Fecha de Aceptación: 28 Agosto, 2014. 
the southern hemisphere that also supply northern hemisphere markets. The main cut flower crops that are produced in Chile are Paeonia, Tulipa and Zantedeschia. During recent decades, the industry has undergone a strong diversification due to the introduction of several other species, including the cut hydrangea (Hydrangea macrophylla). In 2011, exports of Hydrangea accounted for US\$ 38,644, and were $2.36 \%$ of the total cut flower export value (Traub and Vicuña, 2012). Native to Japan, the hydrangea bears an inflorescence formed by small florets (some fertile and some infertile) and colorful big sepals. There is detailed information available about potted hydrangea (Weiler, 1980; Shanks, 1985) and also on garden hydrangea, but little is available on cut hydrangeas.

Hydrangeas are harvested in Chile at 3 different stages, being possible to distinguish among them by the floret development stage and by the sepal color: "fresh" (more than 50\% of florets are open and sepals show a bright color), "transition" (all florets are open and sepals show greenish shades) and "antique" or "classic" (past the "transition" stage) (Figure 1). The stems cut in this last stage are the most durable and have the longest postharvest life because they are less susceptible to dehydration. All flowers, despite the harvesting stage, are transported internationally in cartons via air freight with a water tube placed in the stem base. The heavy weight of the stems and high cost of air transport are compelling the growers to explore the sea transport, which is less expensive but requires good postharvest quality for a longer time. Air transport to the United States currently takes 9 to 12 hours to Miami, while sea transport takes 11 to 19 days to Los Angeles or Philadelphia, USA.
One of the problems to overcome with long term transport of Hydrangea is Botrytis cinerea decay; this fungus attacks during preharvest and also during postharvest. Fungicides have been tested to avoid postharvest botrytis attack in other species (Hammer, 1987; Elad et al., 2003, and Dihn $\&$ Joyce, 2007). Sodium metabisulphite (which reacts with the high relative humidity environment inside the carton, generating sulfur dioxide) gives a good protection against fungal decay in grapes and could be tested in flower crops. Pyrimethanil is available in Chile for botrytis control in several species (AFIPA, 2006-2007).

In addition, ethylene sensitivity at 3-5 ppb has been reported for pot hydrangea (Nowak et al., 1990), but no information is available for cut hydrangea.

On another side, the need to precool or not the flower stems before packing in cartons, and the time needed to reach the desired low temperature in the plant tissue were unsolved questions, so in this experiment these interrogants were addressed.

The objective of this study was to evaluate the long term storage of hydrangea cut flowers harvested in the antique stage, with the aim to explore the feasibility of exporting them by sea transport from Chile to the U.S. market.

\section{Materials and Methods}

Sea transport simulation: Stems of Hydrangea cv. 1, planted in 2008 and grown under shading net were harvested in March 2012, in the antique maturity stage (Figure 1). The flower heads measured 20 to $30 \mathrm{~cm}$ in diameter, and the stem lengths were $50-60 \mathrm{~cm}$. Some of the flower stems included previous season's growth and some had

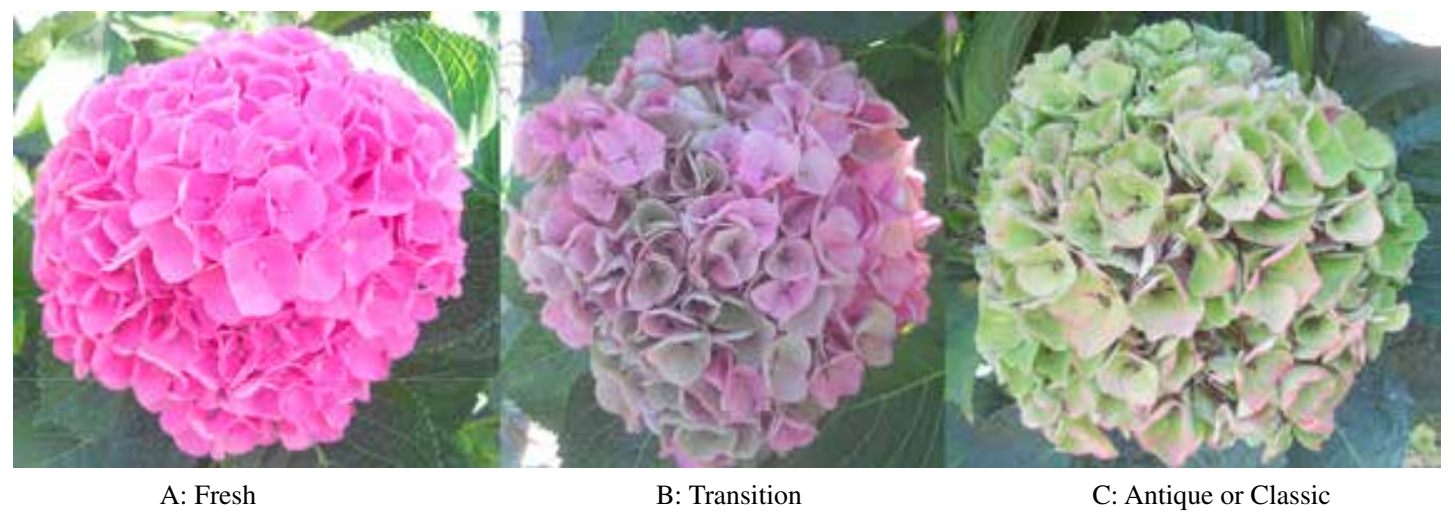

Figure 1. Harvest stages used for cut hydrangeas, cv. Opal. 
only the current season's growth, as result of the pruning management performed by the company. Immediately after harvest in the field, stems were placed in buckets with water. After arrival in the packing shed, stems were placed in a cold room at $5^{\circ} \mathrm{C}$ in water solutions containing Chrysal RVB at $10 \mathrm{ml} \mathrm{L}^{-1}$ for 2 hours. Stems were then trimmed, completely defoliated, graded and packed in cartons (in all cases in number of 8 per carton sized $1 \mathrm{~m} \mathrm{x}$ $0,15 \mathrm{~m} \mathrm{x} 0,15 \mathrm{~m}$ ) with $30 \mathrm{ml}$ water tubes placed at the stem ends, and were transported for 2 hours in a vehicle at $20{ }^{\circ} \mathrm{C}$ to a laboratory in the Universidad de Talca. Stems from 3 treatments were placed outside the cartons in a cold room until they reached the desired temperature of $0.5^{\circ} \mathrm{C}$ (20 minutes). Stems of a $4^{\text {th }}$ treatment were immediately packed upon arrival and cold-stored.

The treatments were:

- Not precooled (immediate packing);

- Precooled for 20 minutes at $0.5^{\circ} \mathrm{C}$;

- Precooled + pyrimethanil (Bonnus 400 SC at 10 $\mathrm{cc} \mathrm{L}^{-1}$ ) sprayed around the flower heads with a manual sprayer in the shed soon after harvest;

- Precooled + sodium metabisulphite (distributed by OSKU S.A., $0.77 \mathrm{~g}$ per carton) placed inside the cartons over sheets of paper to separated from the flower stems.

Cartons in the cold room were placed according to indications by Teeuwen (2012) to promote air circulation (Figure 2). Water consumption was measured every 4 days in extra flower stems placed in an additional carton, with water tubes being refilled

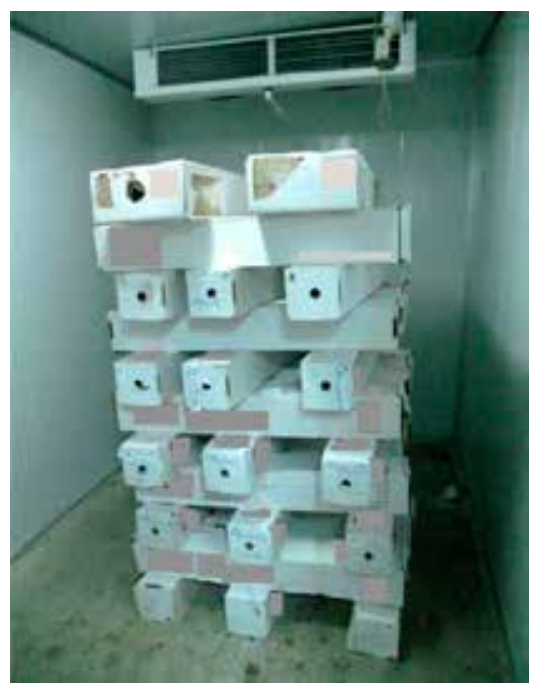

Figure 2. Carton arrangement in the cold room. to their $30 \mathrm{ml}$ level. After storage, flower stems were taken to a laboratory at $20^{\circ} \mathrm{C}$ and received constant 24-hour light supplied by cool white fluorescent tubes. The end of vase life was determined as the day when more than $50 \%$ of the flower head was dehydrated, with a papery sensation when touched, or when wilted. An additional experiment was conducted in March 2013 using cv. 2, to assess vase life of non-stored (freshly harvested) classic flower stems, against the control treatments, under similar conditions as the former experiment.

A randomized experimental design was used, with 6 replications of 8 stems each (48 stems per treatment; 8 stems per carton). Results for vase life were analyzed using ANOVA; when statistical differences were found, LSD test $(\mathrm{p} \leq 0.05)$ was applied. As the flower stems were taken out of the cartons, botrytis incidence was recorded. Botrytis incidence and vase life were assessed after 20 days of cold storage at $0.5{ }^{\circ} \mathrm{C}$. Infected pedicels and peduncles were placed in plastic bags at $8{ }^{\circ} \mathrm{C}$ with high humidity conditions to observe further development of the fungus and confirm the presence of botrytis.

Recorded variables:

Cooling time: Extra stems with water tubes in the stem bases were placed in the cold room at $0{ }^{\circ} \mathrm{C}, 8$ stems were placed inside a carton and 8 in buckets. The instant temperature of the unpacked stems was recorded with an infrared thermometer (EXTECH Instruments 42530), and inside the carton a temperature sensor (HOBO) was used. The time that it took the stems to reach $0.5^{\circ} \mathrm{C}$ was recorded.

Water uptake: 24 Stems with $30 \mathrm{ml}$ water tubes in the bases were placed into 3 separate cartons. Water uptake was recorded every 4 days, and at the same time the tubes were refilled.

Ethylene sensitivity: 10 flower stems were harvested from a garden hydrangea plant, at the fresh stage, and 10 at the antique stage. Half of each group was placed in distilled water, while the other half was placed in distilled water plus $0.4 \mathrm{ml}$ $\mathrm{L}^{-1}$ of Ethylen $48 \mathrm{SL}$ (a.i. ethephon at $480 \mathrm{~g} \mathrm{~L}^{-1}$ ).

Vase life of freshly-harvested stems: Stems of cv. 2 were harvested in March 7, 2013, in the antique stage, and 3 treatments were applied: immediate placement in vases, and two treatments stored at $0{ }^{\circ} \mathrm{C}$ for 20 days, both precooled and non-precooled. 18 stems were used per treatment.

35 days storage: In addition to the former experiment, 32 precooled stems were divided into 
Table 1. Vase life of Hydrangea cv. 1 harvested in the antique stage, with pre-packing treatments and then stored at $0.5{ }^{\circ} \mathrm{C}$ for 20 days.

\begin{tabular}{lc}
\hline Treatment & Vase life (days) \\
\hline No precooling & $9.2 \mathrm{a}$ \\
Precooled & $8.9 \mathrm{a}$ \\
Precooled, pyrimethanil (Bonnus 400 SC, & $8.3 \mathrm{ab}$ \\
$\left.10 \mathrm{cc} \mathrm{L}^{-1}\right)$ & $7.6 \mathrm{~b}$ \\
Precooled, and sodium metabisulphite & \\
$\left(0.77 \mathrm{~g}^{2}\right.$ per carton) & \\
\hline
\end{tabular}

Significance

$*$

Means followed by the same letter are not significantly different, LSD test, $\mathrm{p} \leq 0.05$.

*Significant at $\mathrm{P} \leq 0.05$.

2 groups (precooled and non precooled) and packed in cartons with 8 stems in each. Flower stem bases were placed into water tubes and were placed in the cold room for 35 days, simulating a transport to very long distance markets.

\section{Results}

Sea transport simulation: Most of the water tubes that were placed in the stems bases were dry after 21 days in the cold room. Nevertheless, the vase life was between 7 and 9 days (Table 1). The antifungal treatments were apparently detrimental to vase life, since the stems treated with sodium metabisulphite showed the shortest vase life (7.6 days), not significantly different from the pyrimethanil-treated stems. Botrytis attack was observed on the peduncles and pedicels area of the flower heads of $12.5 \%$ of the precooled-stems treatment. No botrytis infection was observed in the rest of the treatments. The infected stems were used to determine vase life but no further infection was observed.

Cooling time: Before being placed in the cold room, the flowers stems had a temperature of $24^{\circ} \mathrm{C}$. The unpacked stems took 20 minutes to reach the desired temperature of $0.5{ }^{\circ} \mathrm{C}$, while the packed stems took 24 hours.

Water uptake: Although a decreasing water uptake over the 35 days was noted, water uptake was continuous. Total water uptake per stem up to day 21 in the cold room was $42.7 \mathrm{ml}$ (SD 2.59) (Figure 3), value that is over the water tubes' capacity that are currently used $(30 \mathrm{ml})$.

Ethylene sensitivity: Stems that were harvested in the fresh stage showed sepal abscission after 5 days, while stems harvested in the antique stage did not show that symptom. This fact showed that fresh flowers are ethylene sensitive, but antiqueharvested flowers are not.

35 days storage: At the end of the 35 days all the water tubes were completely dry, and the flower stems showed a slight dehydration. Their vase life was only 1.9 days. There was no difference between precooled and non precooled stems. The average water uptake per stem was $63 \mathrm{ml}$ (data not presented).

Vase life of freshly-harvested antique stems: Freshly harvested cut flower stems had a postharvest vase life of 11 days. This value was statistically similar to the vase life of the cut flowers that were not precooled and were stored for 20 days (Table 2), and different, about 2.5 days longer, from the precooled stems. The pattern of postharvest vase life varied: the fresh stems started to finish their vase life at day 8 , without any wilted stems, while the

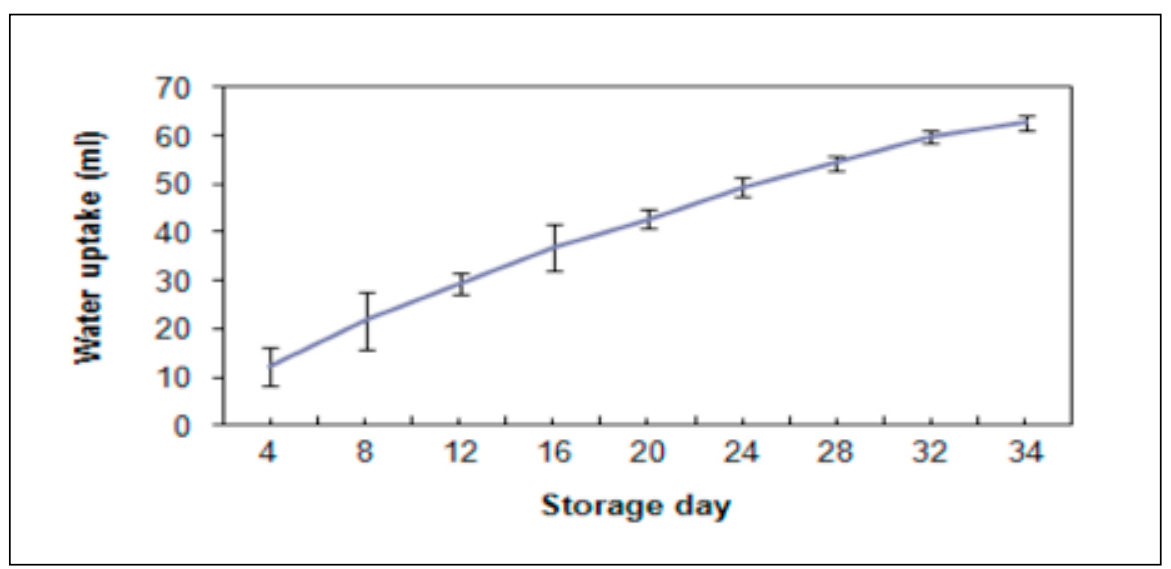

Figure 3. Cumulative water uptake from water tubes in Hydrangea cv. 2 stems during storage at $0.5{ }^{\circ} \mathrm{C}$. 
Table 2. Vase life of freshly -harvested stems of antique Hydrangea cv. 1.

\begin{tabular}{lc}
\hline Treatment & Vase life (days) \\
\hline 20 days-storage at $0.5^{\circ} \mathrm{C}$, precooled & $8.6 \mathrm{~b}$ \\
20 days-storage at $0.5^{\circ} \mathrm{C}$, not precooled & $9.7 \mathrm{ab}$ \\
Freshly-harvested stems & $11.3 \mathrm{a}$ \\
\hline
\end{tabular}

Significance

Means followed by the same letter are not significantly different, LSD test, $\mathrm{p} \leq 0.05$.

*Significant at $\mathrm{P} \leq 0.05$.

long term-stored stems showed some wilted stems during the first days after being placed at $20^{\circ} \mathrm{C}$, as well as stems with the papery sensation at touch or wilting (data not presented).

\section{Discussion}

The long-term dry storage of cut flowers at low temperatures has been studied extensively. Early findings indicate that several species show a good vase life after storage for 2-8 weeks (Sheehan, 1954). In this study, dry storage was not tested; instead, all stems were hydrated during, at least, part of their storage time, until the water from the water tubes was taken up. Previous studies had shown that hydrangea leaves don't survive long term storage, this is the reason why they were trimmed off after harvest. The vase life of freshly-harvested stems of cv. 2 was 11 days, similar to the vase life of nonprecooled stems. On the other side, in order to assure hydration, the water tubes should have at least a 40 $\mathrm{ml}$ capacity, which would greatly increase the weight of the shipping container. In this experiment it did not seem that the stems were negatively affected by the lack of water in the last part of the storage, however, in future studies it would be good to test full hydration during storage vs $30 \mathrm{ml}$, as well as less than $30 \mathrm{ml}$.

Philosoph-Hadas et al. (2010) could reduce fungus decay in Leucadendron 'Safari Sunset' stored for 21 days using Octave (or Sportak) (50\% prochloraz manganese), having $60 \%$ of stem incidence, in contrast with the untreated stems that had $90 \%$ decay after 8 days during vase life evaluation. In the present experiment with hydrangea, one of the untreated treatments showed $12.5 \%$ fungus decay, and no infection was found in the rest of the treatments, so no conclusion is possible in terms of botrytis postharvest control.

In all cases, precooling did not show better results than no precooling, so it should not be recommended.

The storage temperature needed for long term storage in hydrangeas was not available in the reviewed literature. The company's cold room was set at $6{ }^{\circ} \mathrm{C}$ during stem storage before transport to the airport. The temperature used in this experiment $\left(0.5^{\circ} \mathrm{C}\right)$ was successful, in contrast with the temperature of $6{ }^{\circ} \mathrm{C}$ that was used in previous experiments (data not presented).

In future experiments, other conditions should be tested, such as permanent hydration and controlled atmosphere. With the technology used, this long storage is feasible, but further research is needed.

\section{Conclusions}

Hydrangea cv. 1 stems harvested in the antique stage, stored at $0.5^{\circ} \mathrm{C}$ for 21 days showed an acceptable quality (7-9 days of vase life), despite the fact that the water volume in the water tubes placed in the stem ends was not enough for most of the stems. Sea transport is an 11-13 days-journey from Chile to the USA markets, so this kind of transport could be feasible. Storage for 35 days, under the conditons used in this experiment, was not succesful.

Antique-harvested stems appeared to be not susceptible to ethylene, in contrast to fresh-harvested flowers, that show sepal abscission at an early stage.

Botrytis incidence was very low in this experiment (present in around 3\% of the stems), so treatments to control decay could not be tested. Botrytis control under controlled conditions should be addressed in future studies, because it is a frequent postharvest problem.

\section{Acknowledgements}

The authors wish to thank Dr. Christian Krarup from Universidad Católica de Chile, Dr. Michael Reid from University of California for their advice on key aspects of this study, and Dr. Mark Bridgen from Cornell University for his valuable comments and review. 


\section{Literature Cited}

AFIPA (Chilean Association of producers and importers of agricultural phytosanitary products)

2006-2007. Phytosanitary Manual. Facultad de Agronomía e Ingeniería forestal. Pontificia Universidad Católica de Chile (ed.), pp. 525.

Dihn, S-Q.; Joyce, D.C.

2007. Prospects for cut-flower postharvest disease management with host defense elicitors. Stewart Postharvest Review, 3 (2): 1-11.

Elad, Y.; Kirshner, B.; Gotlib, Y.

1992. Attempts to control Botrytis cinerea of rose by pre- and post-harvest treatments with biological and chemical agents. Crop Protection, 12: 69-73.

Hammer, P.

1987. Postharvest control of Borytis cinerea on cut roses with picro-cupric-ammonium formate. Plant Disease, 72: 347-350.

Nowak, J.; Rudnicki, R.

1990. Postharvest handling and storage of cut flowers, florist greens, and potted plants. Timber Press, p. 179.

Philosoph-Hadas, S.; Perzelan, Y.; Rosenberger, I.; Droby, S.; Meir, S.

2010. Leucadendron 'Safari Sunset': posharvest treatments to improve quality of cut foliage during prolonged sea shipment. Acta Hort., 869: 207-217.
Shanks, J.B.

1985. Hydrangeas. In: Ball Red Book, greenhouse growing. Ball, V. (ed.) 1985. Prentice-Hall, Inc. New Jersey, USA., pp. 535-558.

Sheehan, T.J.

1954. Recent advances in the storage of cut flowers. N.Y. State Flower Growers Bulletin 71. Florida State Horticultural Society, United States, p. 7.

Teeuwen, $\mathrm{S}$.

2012. Protocol extends vase life by up to 2 days. Floraculture International. Amsterdam, Holland, pp. 26-27.

Traub, A.J.; Vicuña, B.

2012. Flores de corte: nuevas oportunidades. Published by ODEPA, Office for Agricultural Studies and Policies, Chilean Ministry of Agriculture / Oficina de estudios y Políticas Agrarias, Ministerio de Agricultura, Gobierno de Chile. Available at www.odepa.gob.cl/odepaweb/publicaciones/ doc/4639.pdf. Reviewed: 13/May/2012.

Weiler, T.C.

1980. Hydrangeas, In: Introduction to floriculture. Larson, R. 1980 (ed.). Editorial Academic Press, INC., New York, United States, pp. 353-372. 